\title{
Review
}

\section{Apoptosis: The importance of being eaten}

\author{
Yi Ren $^{1}$ and John Savill, ${ }^{1,2}$ \\ ${ }^{1}$ Division of Renal \& Inflammatory Disease, University Hospital, Nottingham \\ NG7 2UH, UK \\ 2 corresponding author: Division of Renal \& Inflammatory Disease, University \\ Hospital, Nottingham NG7 2UH, UK. tel: 0115970 9985; fax: 0115970 9978; \\ e-mail: john.savill@nottingham.ac.uk
}

Received 3.2.98; revised 10.4.98; accepted 10.4.98

Edited by M. Piacentini

\begin{abstract}
In vivo, cells undergoing apoptosis are usually recognised and swiftly ingested by macrophages or neighbouring cells acting as semi-professional phagocytes. This review debates evidence that the contents of apoptotic cells represent a danger to the organism, being capable of injuring tissue directly or triggering autoimmune responses, concluding that phagocytic clearance of intact apoptotic cells is a safe disposal route. Indeed, new data suggest that, in certain circumstances, phagocytes ingesting apoptotic cells may actively downregulate inflammatory and immune responses. Consequently, increasing evidence that there may be factors capable of perturbing safe clearance of apoptotic cells in vivo suggests that failure of this process may be a hitherto unrecognised pathogenetic factor in inflammatory and autoimmune diseases. New treatments designed to promote safe phagocytic clearance of dying cells can be anticipated, and it may even prove possible to eliminate unwanted cells by inducing appearance of cell surface 'eat me' signals.
\end{abstract}

Keywords: phagocytosis; inflammation; autoimmunity; antiphospholipid autoantibodies

Abbreviations: PS, phosphatidylserine; TSP1, thrombospondin 1; $\mathrm{TNF} \alpha$, tumour necrosis factor- $\alpha$; LPS, lipopolysaccharide; IL-10, interleukin 10

\section{Introduction}

If an apoptotic cell could talk it would say something simple'eat me'. Yet the mechanisms by which phagocytes swiftly recognise, ingest and degrade cells dying by apoptosis are apparently complex and remain poorly understood. This is the case for even the best-characterised 'eat me' signal, exposure of phosphatidylserine (PS), as admirably reviewed by Valerie Fadok and colleagues (Fadok et al, 1998a). Some data suggest that the complexities of phagocyte recognition of apoptotic cells implied by in vitro studies may be illusory, merely representing recognition of PS in different contexts (Pradhan et al, 1997). Nevertheless, we are still faced with a large body of persuasive experiments [reviewed in (Savill, 1997)] which point to involvement of a number of other 'eat me' signals on the surface of apoptotic cells such as sugar changes (Morris et al, 1984; Duvall et al, 1985; Dini et al, 1992; Hall et al, 1994; Dini et al, 1995) and thrombospondin 1 (TSP1) binding sites (Savill et al, 1992a; Stern et al, 1996; Hughes et al, 1997a). Furthermore, there is good evidence for involvement of a plethora of phagocyte receptors (Table 1). The object of this review is to encourage the reader to turn away for a moment from this daunting in vitro complexity and think instead of the in vivo significance of phagocyte clearance of cells dying by apoptosis. The concepts are summarised in Figure 1. Much of what follows is necessarily speculative, because we understand so little of how apoptotic cells are cleared in vivo. Indeed, there seem to be more questions than answers:

\section{Could apoptotic cells directly injure tissue?}

Since the original descriptions of apoptosis (Kerr et al, 1972; Wyllie et al, 1980) it has been assumed that phagocyte clearance of intact cells dying by apoptosis protects surrounding tissues against uncontrolled leakage of noxious contents from dying cells. Nevertheless, it is not immediately obvious that apoptotic cells should be potentially injurious to neighbouring cells. For example, when undergoing apoptosis, dangerous cells such as neutrophils lose the ability to respond to receptor-mediated stimuli which normally trigger injurious responses such as secretion of toxic granule proteins (Whyte et al, 1993). Furthermore, a body of work from Fesus and colleagues (Fesus et al, 1987, 1989, 1991) points to membrane protein cross-linking by tissue transglutaminase during apoptosis, suggesting that the contents of apoptotic cells might be safely sealed inside an insoluble keratin-like cocoon (Piredda et al, 1997). Indeed, in Caenorhabditis elegans nematodes bearing mutations of genes involved in engulfment of unwanted cells dying apoptosis-like developmental deaths, non-ingested cell corpses appear to "hang around' for long periods without obvious disruption of the organism (reviewed in Ellis et al, 1991 and M Hengartner, personal communication). Lastly, even if non-ingested apoptotic cells were to disintegrate in vivo, it could be argued that there are sound defences against potentially injurious cell contents, ranging from inactivation of the acidic lysosomal hydrolases of the dying cell by the near neutral $\mathrm{pH}$ of the interstitium through potent proteinase inhibitors such as $\alpha_{1}$ antitrypsin (Campbell and Campbell, 1988), to the capacity of macrophages and other cells to endocytose dangerous enzymes (Henson and Johnston, 1987).

However, we adhere to the belief that failure of efficient phagocytic clearance of cells dying by apoptosis will result in tissue injury rather than an inconvenient 'cluttering up' of the tissue with tough, non-degradable cell corpses. Firstly, 
despite transglutaminase-mediated cross-linking of membrane protein, virtually every investigator in the field is familiar with secondary necrosis of apoptotic cells in vitro;

Table 1 Phagocyte receptors for apoptotic cells in vitro and some potentia blocking factors which might operate in vivo

\begin{tabular}{|c|c|c|}
\hline Receptor & Possible inhibitors & References \\
\hline 1) Lectins & Polysaccharides & $\begin{array}{l}\text { (Duvall et al, 1985; } \\
\text { Hall et al, 1994; } \\
\text { Dini et al, 1995) }\end{array}$ \\
\hline 2) $\alpha_{v} \beta_{3} / \mathrm{TSP} / \mathrm{CD} 36$ & $\begin{array}{l}\text { RGD-bearing fragments } \\
\text { of adhesion molecules. } \\
\text { Low interstitial pH }\end{array}$ & $\begin{array}{c}\text { (Savill et al, } \\
\text { 1990, 1992) } \\
\text { (Savill et al, 1989) }\end{array}$ \\
\hline 3) PS receptors ${ }^{(b)}$ & $\begin{array}{l}\text { Antiphospholopid } \\
\text { autoantibodies }\end{array}$ & $\begin{array}{l}\text { (Price et al, 1996; } \\
\text { Savill et al, 1997) }\end{array}$ \\
\hline $\begin{array}{l}\text { 4) Scavenger } \\
\text { receptors }\end{array}$ & $\begin{array}{l}\text { Polyanions } \\
\text { Dead cells }\end{array}$ & $\begin{array}{c}\text { (Platt et al, 1996) } \\
\text { (Ottnad et al, 1995) }\end{array}$ \\
\hline 5) CD14 & Endotoxins & (Devitt et al, 1997) \\
\hline 6) $\mathrm{ABC} 1$ & Glyburide-like agents & $\begin{array}{c}\text { (Luciani and } \\
\text { Chimini, 1996; } \\
\text { Hamon et al, 1997) }\end{array}$ \\
\hline
\end{tabular}

${ }^{(a)} \mathrm{RGD}=$ arg-gly-asp tripeptide. ${ }^{(\mathrm{b})} \mathrm{PS}=$ phosphatidylserine in the absence of phagocytes, apoptotic cells eventually lose capacity to regulate cell volume, so that they swell and burst. Secondly, endocytic defences may not be highly effective; in preliminary co-culture experiments in which macrophage phagocytosis of neutrophils undergoing apoptosis was non-specifically blocked with colchicine, non-ingested apoptotic neutrophils undergoing secondary necrosis released large quantities of the potent degradative enzyme neutrophil elastase which eluded endocytic clearance by macrophages (Kar et al, 1993). Thirdly, tissue protective mechanisms operating in interstitial fluid may be inactivated. For example, in perturbed tissues in which cells are dying by necrosis interstitial $\mathrm{pH}$ falls to levels at which released lysosomal enzymes might be active in the extracellular space (Hunt et al, 1985; Menken, 1956). Furthermore, in the microenvironment of a perturbed tissue in which cells are dying, there is evidence that proteinase inhibitors may be oxidatively inactivated (Henson and Johnston, 1987). Finally, although there are other interpretations of the data, administration of anti-Fas antibodies to mice (Ogasawara et al, 1993) probably provides an extreme example of tissue injury consequent

\section{$\underline{\text { SAFE Clearance }}$}

PRIMED M $\varnothing$ (no response) ACTIVATED M

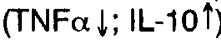

\section{$\underline{\text { UNSAFE Clearance }}$}

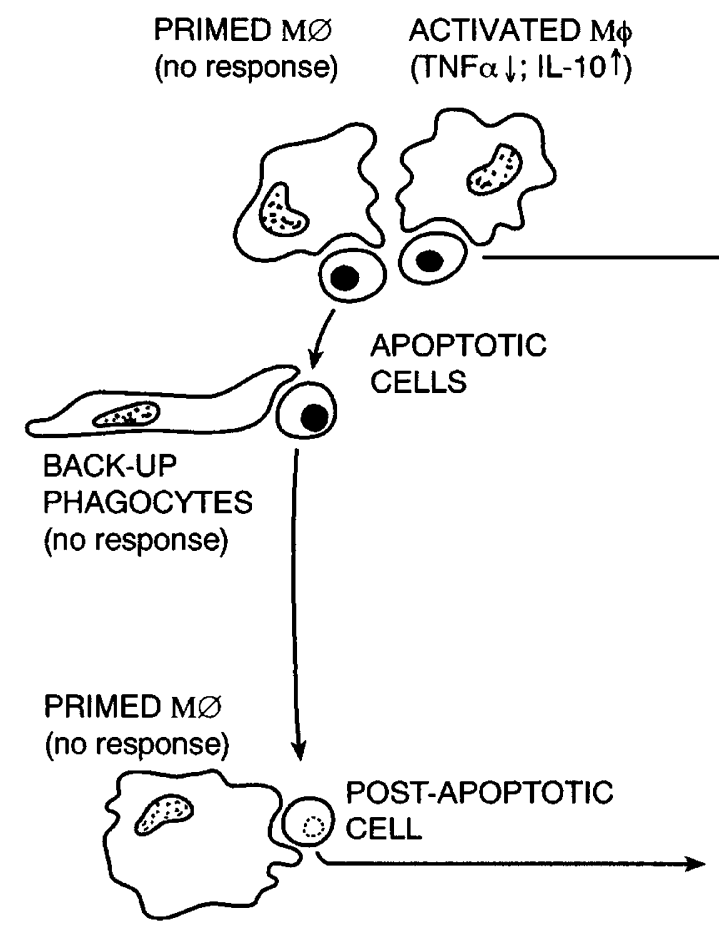

\section{AUTOANTIBODY OPSONISATION} FOR $M \varnothing F C$

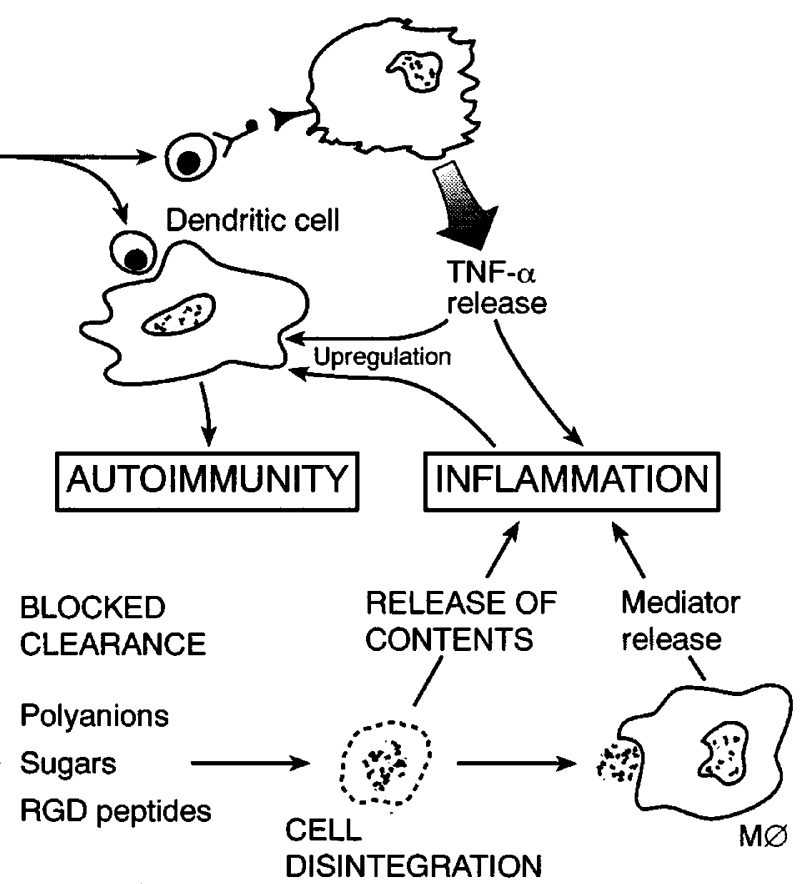

Figure 1 Potential consequences of perturbed phagocyte clearance of cells undergoing apoptosis. Apoptotic cells are safely cleared by primed M $\varnothing$ and back up phagocytes such as mesangial cells without eliciting a pro-inflammatory response; furthermore, primed $\mathrm{M} \varnothing$ can also take up post-apoptotic cells without such responses. Indeed, uptake of apoptotic cells by activated macrophages inhibits TNF release and promotes IL-10 synthesis. Unsafe clearance leading to autoimmunity and inflammation might occur if autoantibodies opsonise apoptotic cells for the Fc receptors of $\mathrm{M} \varnothing$; if apoptotic cells are taken up by dendritic cells so that autoantigens are presented; or if clearance fails with cell disintegration leading to release of pro-inflammatory contents or uptake of debris by $M \varnothing$ which in turn incites release of inflammatory mediators 
upon secondary necrosis of non-ingested apoptotic cells. Because murine hepatocytes express Fas, the antibody triggered rapid and widespread apoptosis of these cells. Presumably because this unphysiologically large load of apoptotic cells exceeded the local phagocytic clearance capacity, non-ingested apoptotic hepatocytes underwent secondary necrosis, releasing their contents in association with a very severe inflammatory response and the ultimate death of the animals receiving active anti-Fas antibody.

Definitive evidence in support of the potentially injurious nature of apoptotic cells requires experiments which as yet cannot be performed-specific blockade in vivo of largescale phagocyte clearance of apoptotic cells. However, it will also be important to consider the possibility that the surface of non-ingested apoptotic cells might be dangerous in that exposed PS could trigger undesirable coagulation in vascular spaces (Fadok et al, 1992; Casciola-Rosen et al, 1996), an outcome supported by our recent observations in a model of glomerular capillary injury in which recruited neutrophils remain intraluminal-apoptotic cells were usually found within areas of newly formed thrombus (Hughes et al, 1997b). On balance, therefore, the available evidence supports the assumption that phagocyte clearance of intact cells dying by apoptosis does protect tissues from inflammatory and coagulative injury initiated by cellular constituents. However this conclusion does not address the next question which arises.

\section{Is phagocytosis a safe means of cell clearance?}

The generally inconspicuous nature of cell removal by apoptosis leading to phagocytosis has lent weight to the idea that this is a safe means of disposal of unwanted cells. However, a sceptic might point to the fact that uptake of particles normally triggers proinflammatory responses (Nathan, 1987) from macrophages, the professional phagocytes implicated in clearing large loads of apoptotic cells in the liver and spleen, bone marrow, lymph node and inflamed site. Indeed, the possibility that uptake of apoptotic cells may trigger proinflammatory responses from ingesting phagocytes finds support in reports that cells dying by apoptosis may fix complement, opsonising apoptotic cells for macrophage receptors which may be coupled to secretion of inflammatory mediators (Takizawa et al, 1996).

However, uptake of large numbers of apoptotic cells fails to stimulate pro-inflammatory secretory responses from cultured monocyte-derived macrophages and glomerular mesangial cells (Meagher et al, 1992; Stern et al, 1996; Hughes et al, 1997a; Fadok et al, 1998b). In no case have phagocytes been observed to release any of a wide range of potentially injurious mediators, including granule enzymes, thromboxane, tumour necrosis factor- $\alpha$ (TNF $\alpha)$ and chemokines. This lack of response was not due to some toxic effect of ingested apoptotic cells upon macrophages, since appropriate responses were observed if a second stimulus such as opsonised zymosan was used, or if apoptotic cells were deliberately opsonised for macrophage immunoglobulin or complement receptors (Meagher et al, 1992).
Indeed, evidence is now accumulating that when macrophages which have been deliberately stimulated with agents such as lipopolysaccharide take up apoptotic cells, far from pro-inflammatory responses, one observes 'anti-inflammatory' phenomena. These include down-regulation of LPS-stimulated macrophage release of TNF $\alpha$ and increased secretion of interleukin-10 (IL10), which amongst other immunosuppressive effects is capable of 'deactivating' macrophages Voll et al, 1997; Fadok et al, 1998). Thus, despite the fact that uptake of particles generally leads to activation of phagocytes, there are now compelling in vitro data to suggest that recognition and uptake of intact apoptotic cells is likely to be a safe means of disposal which is uncoupled from inflammatory responses. In vivo support for this idea is so far indirect but strong; in organs such as the thymus, macrophages can ingest massive numbers of apoptotic cells in the absence of inflammation (Surh and Sprent, 1994). However, we need to consider how tissues might be protected should 'front line' mechanisms for clearing apoptotic cells fail.

\section{Are back-up clearance mechanisms available?}

So far we have presented arguments that apoptosis leading to phagocyte clearance is a safe way of deleting unwanted dying cells, which if allowed to disintegrate might injure tissue. Indeed, some data suggest that this could be doubly deleterious. Thus, if macrophages were 'fed' cell debris from cultured eosinophils which had been allowed to proceed through constitutive apoptosis to secondary necrosis, proinflammatory responses were elicited (Stern et al, 1996). Consequently, one might wonder whether capacity to clear apoptotic cells in vivo might not be 'backed up' in some way.

Tissues may be able to recruit capacity to ingest intact apoptotic cells in a number of ways. Firstly, many cell types may be able to participate in the clearance job. In the inflamed glomerulus, for example, it is possible that mesangial cells back up macrophages (Savill et al, 1992b; Baker et al, 1994; Hughes et al, 1997), while in the developing nervous system a number of cell types, including neuronal and glial cells, exhibit capacity to ingest apoptotic cells (Chu-Wang and Oppenheim, 1978; Ashwell, 1990; Parnaik, 1998). Secondly, local conditions may give phagocytes a boost-such as the potentiating effects of various inflammatory cytokines upon uptake of apoptotic cells by cultured macrophages (Ren and Savill, 1995) or via ligation of CD44 (Hart et al, 1997). Thirdly, there is the interesting possibility that dying cells might emit 'come hither' signals to phagocytes in order selectively to recruit more clearance capacity. This idea is difficult to test either in vitro or in vivo, because death in any cell population tends to be asynchronous, so that a few cells undergoing secondary necrosis might generate chemotactic signals either directly or indirectly by acting on healthy cells. Consequently, observations that phagocytes migrate towards groups of cells undergoing apoptosis must be treated with some caution (Parnaik, 1998).

However, quite apart from increasing the numbers of 'hunter' phagocytes in a tissue undergoing large-scale 
death by apoptosis, it might also be possible to prevent dangerous leakage of contents from dying cells by equipping the 'prey' with additional means of being captured and eaten. To date there has been little systematic study of display of 'eat me' signals as dying cells progress through apoptosis toward secondary necrosis. Although in some cell types PS exposure may precede nuclear changes of apoptosis by several hours (reviewed in Fadok et al, 1998a), in the case of well-studied phagocytic targets such as cultured neutrophils undergoing constitutive apoptosis, PS exposure seems more or less synchronous with display of TSP1 binding sites recognisable to macrophages employing the $\alpha_{\mathrm{v}} \beta_{3}$ vitronectin receptor/TSP1/CD36 phagocytic mechanism (Brown et al, 1997). Nevertheless, constitutive apoptosis in cultured neutrophils does afford the opportunity to study phagocyte recognition of intact cells which are 'post-apoptotic' in that they are undergoing late degradative changes such as the loss of nuclear structures identified by Hébert et al (1996) as 'nuclear evanescence'. We have succeeded in purifying such cells and have discovered that they are recognised by a novel mechanism involving $\alpha_{v} \beta_{3}$ and TSP1 but not CD36, even when being taken up by murine thioglycollate-elicited peritoneal macrophages, which predominantly employ PS receptors in uptake of 'early' apoptotic cells (Savill et al, 1996).

Thus, there is clear evidence that during death by apoptosis, cells can display a temporally defined series of 'eat me' signals which provide phagocytes with the opportunity to deploy a hierarchy of recognition mechanisms which can be regarded as a series of protective 'backups'. Indeed, the possible last line of tissue defence represented by CD36-independent $\alpha_{v} \beta_{3} /$ TSP-mediated macrophage recognition of 'post-apoptotic' neutrophils appears also to be uncoupled from pro-inflammatory responses (Ren and Savill, unpublished data). Nevertheless, given that CD36 may be needed for production of immunosuppressive IL10 (Voll et al, 1997) and that professional antigen presenting cells such as dendritic cells deploy a CD36 independent $\alpha_{v}$-mediated recognition mechanism in uptake of apoptotic cells (Rubartelli et al, 1997), these data stimulate a fourth important question -

\section{Could cells dying by apoptosis trigger undesirable immune responses?}

In addition to having capacity to injure tissues directly, the contents of cells dying by apoptosis also have potential to trigger undesirable immune responses. Firstly, apoptotic cell contents might act as non-specific adjuvants, since free oligonucleosomes (generated in dying cells by apoptotic endonucleases) can stimulate DNA and immunoglobulin synthesis in viable lymphocytes (Bell and Morrison, 1991). Secondly, in individuals with pre-existing autoimmune disease, cell death by apoptosis may be dangerous in that auto antigens may become more accessible. For example, Rosen's group demonstrated beautifully that important nuclear autoantigens such as Ro and La may be selectively redistributed into cell surface blebs which can detach as apoptotic bodies (Casciola-Rosen et al, 1994). Failed phagocytic clearance and release of autoantigen from disintegrating apoptotic bodies could potentiate presentation of constituent autoantigenic peptides. Thirdly, the Rosen group have also made the fascinating suggestion that during apoptosis enzymes such as caspases may degrade cellular proteins and thereby generate fragments which represent neoantigens capable of triggering autoimmune responses in susceptible individuals (Casciola-Rosen et al, 1995).

However, at the time of writing there has been very little study of the immunological consequences of phagocyte ingestion of cells dying by apoptosis. The importance of such work has been re-emphasised by the recent discovery that in addition to copious reports of phagocytosis by activated macrophages known to express class II MHC, dendritic cells can also ingest apoptotic cells (Rubartelli et al, 1997). Until very recently, we have had little data beyond the intriguing study of Griffith and colleagues (Griffith et al, 1996), which is open to several interpretations. Administration of antigen-coupled cells into the eye demonstrated that systemic immunity developed of these cells died by necrosis, but not if the administered cells died by apoptosis and were cleared by phagocytes - tolerance to the antigen was observed. However, using monocytes induced into apoptosis by infection with influenza virus, Albert and colleagues have made the extremely interesting observation that uptake of such cells by dendritic cells leads to $\mathrm{MHC}$ class I presentation of influenza peptides derived from the 'apoptotic meal' and induction of appropriately restricted CD8+ve $\mathrm{T}$ cells (Albert et al, 1998). Nevertheless, uptake of apoptotic monocytes bearing influenza antigen by monocyte-derived macrophages, rather than dendritic cells, failed to elicit cytolytic $T$ cells, as one might expect from the Griffith study.

We urgently need further work on whether particular phagocyte populations can present peptides derived from ingested dying cells are presented via MHC class I and class II molecules to T cells, and if so whether this occurs in a context likely to stimulate $\mathrm{T}$ cell proliferation or anergy; the capacity to present antigens derived from apoptotic cells may prove limited to the most professional of antigen presenting cells, the dendritic cell. However, these experiments will require careful attention to detail, employing well-defined populations of 'target' apoptotic or postapoptotic cells, since it will be important to exclude confounding cytokine production consequent upon uptake of debris from apoptotic cells undergoing secondary necrosis. Indeed, if we are to take proper account of possible co-stimulatory signals, another question must be addressed.

\section{What might perturb safe phagocytic clearance of apoptotic cells?}

Lack of data means that this must be the most speculative section of an article with more questions than answers. In vitro data, much of a preliminary nature, suggests that a number of factors could block clearance of apoptotic cells in vivo (Table 1). Antiphospholipid autoantibodies (aPL) were first described in $20-40 \%$ of patients with systemic lupus erythematosus (SLE) as anti-cardiolipin antibodies, but are now known to 
Table 2 Approaches toward increasing phagocytic clearance of dying cells

\begin{tabular}{|c|c|c|}
\hline Aim & Approach & Reference \\
\hline \multirow[t]{2}{*}{$\begin{array}{l}\text { 1) Stimulate macrophage } \\
\text { phagocytosis }\end{array}$} & Cytokines & $\begin{array}{c}\text { (Ren and } \\
\text { Savill, 1995) }\end{array}$ \\
\hline & $\begin{array}{l}\text { CD44 ligation } \\
\text { Glucocorticoids }\end{array}$ & $\begin{array}{c}\text { (Hart et al, 1997) } \\
\text { (Liu et al, 1997) }\end{array}$ \\
\hline \multirow[t]{3}{*}{$\begin{array}{l}\text { 2) Enhance semi-professional } \\
\text { phagocytosis }\end{array}$} & $\begin{array}{l}\text { Cytokines } \\
\text { Cys }\end{array}$ & $\begin{array}{l}\text { (Bennett } \\
\text { et al, 1995) }\end{array}$ \\
\hline & Glucocorticoids & (Liu et al, 1997) \\
\hline & $\begin{array}{l}\text { CD36 gene } \\
\text { transfer }\end{array}$ & (Ren et al, 1995) \\
\hline
\end{tabular}

occur in a number of related autoimmune conditions (Hughes and Khamashta, 1994). The role of aPL in disease pathogenesis remains uncertain, but aPL are known to recognise a complex of the plasma protein $\beta_{2}$ glycoprotein I $\left(\beta_{2} \mathrm{GPI}\right)$ with anionic phospholipids including phosphatidylserine, which is exposed by apoptotic cells. Importantly, as one might expect, Levine's group (Price et al, 1996) have confirmed that aPL can bind to apoptotic but not normal cells in a $\beta_{2} \mathrm{GPI}$-dependent manner. A number of laboratories are now investigating the possibility that this may perturb safe clearance of apoptotic cells, either by opsonising apoptotic cells so that macrophages incite inflammation or autoimmunity (Manfredi et al, 1998), or by blocking clearance by phagocytes which do not bear receptors for opsonic immunoglobulin (Savill et al, 1997). This line of enquiry emphasises that some factors perturbing clearance of apoptotic cells might also have synergistically deleterious effects. Consequently, the physician might ask a final question.

\section{Could safe clearance of apoptotic cells be promoted for therapeutic gain?}

Again, the available data only allow a speculative answer, but there does seem some prospect of being able to enhance clearance of apoptotic cells (Table 2). This could represent a novel approach to therapy of inflammatory and autoimmune disorders. Furthermore, concomitant promotion of safe phagocytic clearance might be an important adjunct to possible future therapies designed to eliminate dangerous or unwanted cells, such as tumour cells, by triggering apoptosis. Indeed, such therapies could be based on directing unscheduled phagocytosis of unwanted cells, by inducing them to express 'eat me' signals without undergoing programmed cell death. We have been encouraged by preliminary studies (Knepper-Nicolai et al, 1996) which suggest that hidden within the apparently single program of apoptosis there may be a partially independent program controlling cell surface changes, which might be amenable to selective triggering.

\section{Conclusions}

Before we can appreciate the full significance of the familiar phenomenon of swift phagocytic clearance in vivo of cells dying by apoptosis, we need a much more sophisticated understanding of the recognition systems involved and their position in a putative hierarchy of disposal mechanisms. Nevertheless, there are now tantalising clues that perturbed clearance may be a hitherto unrecognised factor in the pathogenesis of inflammatory and autoimmune diseases. Indeed, it may prove possible to design therapies which enhance or even direct safe phagocytic clearance of unwanted or dangerous cells.

\section{References}

Albert ML, Sauter B and Bhardwaj N (1998) Dendritic cells acquire antigen from apoptotic cells and induce class 1-restricted CTLs. Nature 392: 86-89

Ashwell K (1990) Microglia and cell death in the developing mouse cerebellum. Develop Brain Res. 55: 219-230

Baker AJ, Mooney A, Hughes J, Lombardi D, Johnson RJ and Savill J (1994) Mesangial cell apoptosis: The major mechanism for resolution of glomerular hypercellularity in experimental mesangial proliferative nephritis. J. Clin. Invest. 94: $2105-2116$

Bell DA and Morrison B (1991) The spotaneous apoptotic death of normal human lymphocytes in vitro: The release of and immunoroliferative response to nucleosomes in vitro. Clin. Immunol. Immunopath. 60: 13-26

Bennett MR, Gibson DF, Schwartz SM and Tait JF (1995) Binding and phagocytosis of apoptotic vascular smooth muscle cells is mediated in part by exposure of phosphatidylserine. Circ. Res. 77: 1136-1142

Brown SB, Bailey Kand Savill J (1997) Actin is cleaved during constitutive apoptosis. Biochem. J. 323: 233-237

Campbell EJ and Campbell MA (1988) Cellular proteolysis by neutrophils in the presence of proteinase inhibitors: effects of substrate opsonization. J. Cell Biol. 106: $667-675$

Casciola-Rosen LA, Anhalt G and Rosen A (1994) Autoantigens targeted in systemic lupus erythematosus are clustered in two populations of surface structures on apoptotic keratinocytes. J. Exp. Med. 179: 1317-1330

Casciola-Rosen LA, Anhalt GJ and Rosen A (1995) DNA-dependent protein kinase is one of a subset of autoantigens specifically cleaved early during apoptosis. J. Exp. Med. 182: 1625-1634

Casciola-Rosen L, Rosen A, Petri M and Schlissel M (1996) Surface blebs on apoptotic cells are sites of enhanced procoagulant activity: Implications for coagulation events and antigenic spread in systemic lupus erythematosus. Proc Natl Acad Sci USA 93: 1624-1629

Chu-Wang IW and Oppenheim RW (1978) Cell death of motorneurons in the chick embryo spinal cord I. A light and electron microscopic study of naturally occurring and induced cell loss during development. J. Comp. Neurol. 177: 33-57

Devitt A, Raykundalia C, Moffatt OD, Capra JD, Simmons DL and Gregory CD (Submitted 1997) Human CD14 mediates recognition and phagocytosis of cells undergoing apoptosis

Dini L, Autori F, Lentini A, Olivierio S and Piacentini M (1992) The clearance of apoptotic cells in the liver is mediated by the asialoglycoprotein receptor. FEBS Lett. 296: $174-178$

Dini L, Lentini A, Diez GD, Rocha M, Falasca L, Serafino L and Vidal-Vanaclocha F (1995) Phagocytosis of apoptotic bodies by liver endothelial cells. J. Cell. Sci. 108: $967-973$

Duvall E, Wyllie AH and Morris RG (1985) Macrophage recognition of cells undergoing programmed cell death. Immunol. 56: 351-358

Ellis RE, Yuan J and Horvitz HR (1991) Mechanisms and functions of cell death. Annu. Rev. Cell Biol. 7: 663-698

Fadok VA, Bratton DL, Frasch SC, Warner ML and Henson PM (1998a) The role of phosphatidylserine in recognition of apoptotic cells by phagocytes. Cell Death and Differentiation - In Press

Fadok VA, Bratton DL, Konowal A, Freed PW, Westcott JY and Henson PM (1998b) Macrophages that have ingested apoptotic cells in vitro inhibit proinflammatory cytokine production through autocrine/paracrine mechanisms involving TGF $\beta$, PGE2 and PAF. J. Clin. Invest. 101: 890-898

Fadok VA, Voelker DR, Campbell PA, Cohen JJ, Bratton DL and Henson PM (1992) Exposure of phosphatidylserine on the surface of apoptotic lymphocytes triggers specific recognition and removal by macrophages. J. Immunol. 148: 2207-2216 
Fesus L, Davies PJA and Piacentini M (1991) Apoptosis - molecular mechanisms in programmed cellular death. Eur. J. Cell Biol. 56:170-177.

Fesus L, Thomazy V, Autuori F, Ceru MP, Tarcsa E and Piacentini M (1989) Apoptotic hepatocytes become insoluble in detergents and chaotropic agents as a result of transglutaminase action. FEBS Lett. 245: 150-154

Fesus L, Thomazy V and Falus A (1987) Induction and activation of tissue transglutaminase during programmed cell death. FEBS Lett. 224: 104-108

Griffith TS, Yu X, Herndon JM, Green DR and Ferguson TA (1996) CD95-induced apoptosis of lymphocytes in an immune privileged site induces immunological tolerance. Immunity 5: 7-16

Hall S, Savill J, Henson P and Haslett C (1994) Apoptotic neutrophils are phagocytosed by fibroblasts with participation of the fibroblast vitronectin receptor and involvement of a mannose/fucose-specific lectin. J. Immunol. 153: $3218-3227$

Hamon Y, Luciani M-F, Becq F, Verrier B, Rubartelli A and Chimini G (1997) Interleukin- $1 \beta$ secretion is impaired by inhibitors of the ATP binding cassette transporter, ABC1. Blood 90: 2911-2915.

Hart SP, Dougherty GJ, Haslett C and Dransfield I (1997) CD44 regulates phagocytosis of apoptotic neutrophil granulocytes, but not apoptotic lymphocytes, by human macrophages. J. Immunol. 159: 919-925

Hébert M-J, Takano T, Holthöfer H and Brady HR (1996) Sequential morphological events during apoptosis of human neutrophils. J. Immunol. 157: 3105-3115

Henson PM and Johnston RB (1987) Tissue injury in inflammation. Oxidants, proteinases and cationic proteins. J. Clin. Invest. 79: 669-674

Hughes GRV and Khamashta MA (1994) The antiphospholipid syndrome. J. Roy. Coll. Phys. Lond. 28: 301-304

Hughes J, Johnson RJ, Mooney A, Hugo C, Gordon K and Savill J (1997b) Neutrophil fate in experimental glomerular capillary injury in the rat: Emigration exceeds in situ clearance by apoptosis. Am. J. Pathol. 150: 223-234

Hughes J, Liu Y, Van Damme J and Savill J (1997a) Human glomerular mesangial cell phagocytosis of apoptotic neutrophils: Mediation by a novel CD36-independent vitronectin receptor/thrombospondin recognition mechanism that is uncoupled from chemokine secretion. J. Immunol. 158: 4389-4397

Hunt TK, Banda MJ and Silver IA (1985) Cell interactions in post-traumatic fibrosis. Ciba Found Symp. 114: 127-149

Kar S, Ren Y, Savill JS and Haslett C (1993) Inhibition of macrophage phagocytosis in vitro of aged neutrophils increases release of neutrophil contents. Clin. Sci. 85 27p (Abstract)

Kerr JFR, Wyllie AH and Currie AR (1972) Apoptosis: a basic biological phenomenon with widespread implications in tissue kinetics. Br. J. Cancer 26: 239-257

Knepper-Nicolai B, Brown SB and Savill J (1996) Inhibition of Type 1 calpain dissociates recognition by macrophages from other features of constitutive apoptosis in the neutrophil. J. Leuk. Biol. Suppl. 1996: 39

Liu Y, Savill J, Van Damme J and Hughes J (1997) Glucocorticoid steroids increase uptake of apoptotic cells by glomerular phagocytes. J. Am. Soc. Nephrol. 8: 501A

Luciani MF and Chimini G (1996) The ATP binding cassette transporter ABC1, is required for engulfment of corpses generated by apoptotic cell death. EMBO J. 15: $226-235$

Manfredi AO, Rovere P, Galati G, Heltai S, Bozzolo E, Soldini L, Davoust J, Balestrieri G, Tincani A and Sabbadini MG (1998) Apoptotic cell clearance in systemic lupus erythematosus. Arth. Rheum. 41: 205-214

Meagher LC, Savill JS, Baker A and Haslett C (1992) Phagocytosis of apoptotic neutrophils does not induce macrophage release of Thromboxane B2. J. Leuk. Biol. 52: 269-273

Menken V (1956) Biology of inflammation: chemical mediators and cellular injury. Science 123: 527-534

Morris RG, Hargreaves AD, Duvall E and Wyllie AH (1984) Hormone induced cell death 2 . Surface changes in thymocytes undergoing apoptosis. Am. J. Pathol 115: $426-436$

Nathan C (1987) Secretory products of macrophages. J. Clin. Invest. 79: 319-326

Ogasawara J, Watanabe-Fukunaga R, Adachi M, Matsuzawa A, Kasugai T, Kitamura Y, Itoh, N, Sudah T and Nagata S (1993) Lethal effect of the anti-Fas antibody in mice. Nature 364: 806-809
Ottnad E, Parthasarathy S, Sambrano R, Ramprasad MP, Quehenberger O, Kondratenko N, Green S and Steinberg D (1995) A macrophage receptor for oxidized low density lipoprotein distinct from the receptor for acetyl low density lipoprotein: Partial purification and role in recognition of oxidatively damaged cells. Proc. Natl. Acad. Sci. USA 92: 1391-1395

Parnaik R (1998) 1PhD Dissertation. University of London

Piredda L, Amendola A, Colizzi V, Davies PJA, Farrace MG, Fraziano M, Gentile V, Uray I, Piacentini M and Fesus L (1997) Lack of 'tissue' transglutaminase protein cross-linking leads to leakage of macromolecules from dying cells: relationship to development of autoimmunity in MRLIpr/lpr mice. Cell Death and Differentiation 4: 463-472

Platt N, Suzuki H, Kurihara Y, Kodama T and Gordon S (1996) Role for the class A macrophage scavenger receptor in the phagocytosis of apoptotic thymocytes in vitro. Proc. Natl. Acad. Sci. USA 93: 12456-12460

Pradhan D, Krahling S, Williamson P and Schlegel RA (1997) Multiple systems for recognition of apoptotic lymphocytes by macrophages. Mol. Biol. Cell. 8: $767-$ 778

Price BE, Rauch J, Shia MA, Walsh MT, Lieberthal W, Gilligan HM, O'Laughlin T, Koh JS and Levine JS (1996) Anti-phospholipid autoantibodies bind to apoptotic, but not viable, thymocytes in a $\beta_{2}$-glycoprotein I-dependent manner. J. Immunol. 157: $2201-2208$

Ren Y and Savill J (1995) Pro-inflammatory cytokines potentiate thrombospondinmediated phagocytosis of neutrophils undergoing apoptosis. J. Immunol. 154: $2366-2374$

Ren Y, Silverstein RL, Allen J and Savill J (1995) CD36 gene transfer confers capacity for phagocytosis of cells undergoing apoptosis. J. Exp. Med. 181: 1857-1862

Rubartelli A, Foggi A and Zocchi MK (1997) The selective engulfment of apoptotic bodies by dendritic cells is mediated by the $\alpha_{v} \beta_{3}$ integrin and requires intracellular and extracellular calcium. Eur. J. Immunol. 27: 1893-1900

Savill J (1997) Recognition and phagocytosis of cells undergoing apoptosis. Brit. Med. Bulletin 53 (No 2): 5.1-18

Savill J, Dransfield I, Hogg N and Haslett C (1990) Vitronectin receptor mediated phagocytosis of cells undergoing apoptosis. Nature 343: 170-173

Savill JS, Henson PM and Haslett C (1989) Phagocytosis of aged human neutrophils by macrophages is medicated by a novel 'charge sensitive' recognition mechanism. J. Clin. Invest. 84: 1518-1527

Savill J, Hogg N, Ren and Haslett C (1992a) Thrombospondin cooperates with CD36 and the vitronectin receptor in macrophage recognition of neutrophils undergoing apoptosis. J. Clin. Invest. 90: 1513-1522

Savill J, Ren Y, Church H, Loizou S, Walport M and Brown S (1997) A new candidate mechanism for tissue injury in autoimmunity: Autoantibodies that bind apoptotic cells block clearance by macrophages (Mf). J. Am. Soc. Nephrol. 8: 484A

Savill J, Ren Y, Stern M and Haslett C (1996) Uptake of post-apoptotic granulocytes via a novel polyanion-inhibitable recognition mechanism. J. Am. Soc. Nephrol.7: 1719

Savill JS, Smith J, Ren Y, Sarraf C, Abbott F and Rees AJ (1992b) Glomerular mesangial cells and inflammatory macrophages ingest neutrophils undergoing apoptosis. Kid. Int. 42: 924-936

Stern M, Savill J and Haslett C (1996) Human monocyte-derived macrophage phagocytosis of senescent eosinophils undergoing apoptosis: Mediation by $\alpha v \beta 3 / C D 36 /$ thrombospondin recognition mechanism and lack of phlogistic response. Am. J. Pathol. 149/3: 911-921

Surh CD and Sprent JJ (1994) T-cell apoptosis detected in situ during positive and negative selection in the thymus. Nature 372: $100-103$

Takizawa F, Tsuji S and Nagasawa S (1996) Enhancement of macrophage phagocytosis upon iC3b deposition on apoptotic cells. FEBS Lett. 397:269-272

Voll RE, Herrmann M, Roth EA, Stach C and Kalden JR (1997) Immunosuppressive effects of apoptotic cells. Nature 390: $350-351$

Whyte MKB, Meagher LC, MacDermot J and Haslett C (1993) Impairment of function in aging neutrophils is associated with apoptosis. J. Immunol. 150: 5124-5134

Wyllie AH, Kerr JFR and Currie AR (1980) Cell death: the significance of apoptosis. Int. Rev. Cytol. 68: 251-306 